\title{
LETTERS
}

\section{Need reforms in medical education}

The recent controversy on the efforts made by the Medical Council of India and the government of India to bring transparency in medical education highlights the urgent need for reforms in this area.

The present system of medical education does not assure the option to re-total marks or call for re-examination when doubts are raised about the quality of assessment.

Further, students who report unfair practices in assessment during a university examination for a medical degree have no avenues of redress, which compounds their agony as their future is harmed. A newspaper recently reported on a reexamination at the Rajiv Gandhi University of Health Sciences (RGUHS) in Karnataka for a single student. This was a practical examination in oral medicine and radiology for the final year in the Bachelor in Dental Surgery programme. The Chancellor of RGUHS made a landmark decision in the history of medical education by conducting the re-examination after consulting experts who judged that the examination was improperly assessed. Other medical universities should consider amending their rules for conducting medical examinations. They should provide students opportunities for reexamination if they can demonstrate that their examinations had been unfairly assessed.

N Manjunatha, Department of psychiatry, National Institute of Mental Health and Neuro Sciences (NIMHANS), Bangalore 560029 INDIA email:manjunatha.adc@gmail.com

\section{References}

1. Pandya SK. Medical Council of India: the rot within. Indian J Med Ethics [Internet].2009 Jul-Sep [cited 2009 Nov 25];6(3): 125-31.

2. Hira RS, Gupta AK, Salvi VS, Ross MW. Medical education in Maharashtra: the student perspective. J Postgrad Med [Internet] 2009;55(2):127-30. Available from: http://www.jpgmonline.com/article.asp?issn=0022-38 59 ;year $=2009 ;$ volume $=55 ;$ issue $=2 ;$ spage $=127$;epage $=130 ;$ aulast $=$ Hira\# cited

3. Times News Network. Re-exam held for single student! Sunday Times of India [Internet]. (Bangalore Ed.). 2009 Sep 6 [cited 2009 Nov 25]; Times city: 4(col.2). Available from: http://epaper.timesofindia.com/Archive/ skins/pastissues2/navigator.asp?AW=1259137243703

\section{Opportunities for internships in ethics}

Centre for Studies in Ethics and Rights (CSER) was set up in January 2005 by the Anusandhan Trust (AT) to undertake research in ethics and human rights.

CSER is engaged in research and training in ethics, rights and capacity building of voluntary organisations/NGOs. It organises training programmes in various fields, including bioethics, ethics in clinical trials and programme management. Our priority areas include professional ethics, research bioethics, public heath ethics, development ethics, law, human rights and ethics, comparative ethics, and exploring linkages between the discourses in ethics and rights in the Indian context.

CSER faculty members include social scientists, medical professionals, bioethicists and public health practitioners. These include Dr Amar Jesani, Dr Nobhojit Roy, Dr Padma Prakash, Ms Padma Deosthali, Ms Sandhya Srinivasan, Ms Pranoti Chirmuley and Ms Neha Madhiwalla.

CSER offers internships to graduate, postgraduate and doctoral students from the fields of medicine, law, social work, social sciences and others who are interested in these areas of study. Faculty at CSER offers mentorship through out the internship period and resources like; libraries and documentations centres of CSER and CEHAT in Mumbai can be accessed by the intern. Interns will be expected to do a time-bound project or assignment to the satisfaction of CSER faculty. Certificates of experience will be provided to the students.

The internships are for a minimum of six weeks and can extend to six months. An intern from Mumbai and outstation who has an accommodation facility in Mumbai will get Rs. 8000/- as stipend. Any Intern from outstation who does not have any accommodation in Mumbai will get Rs.12, 000/- as stipend. CSER will offer partial support. CSER will cover the costs of any local travel and related expenses incurred by the intern while doing project-related work.

Interested applicants can email Mr Shinde [mahendra.cser@gmail.com or (call +91-22-2668 1568)], with updated resumes, areas of interest and contact details. A faculty member will follow up with the applicant. Interns will be selected based on their interests, skills, experience and requirement of the centre. 